\title{
CLAVES HERMENEUTICAS PARA UNA REFLEXIÓN TEOLÓGICA
}

\section{HERMENEUTICAL KEYS FOR A THEOLOGICAL REFLECTION}

\author{
Antonio Bentué ${ }^{1}$ \\ Pontificia Universidad Católica de Chile \\ ORCID: 0000-0001-9404-7587
}

https://doi.org/10.21703/2735-6345.2021.22.02.004

Recibido: 28.12.2020

Aceptado: 20.04.2021

\section{Resumen}

Este artículo intenta mostrar el proceso histórico experimentado por la hermenéutica aplicada al mensaje bíblico, en la dialéctica entre la postura tradicionalista y la inculturación adaptadora de la Palabra, tal como lo postula el Vaticano II. Mostrando la necesidad de esa inculturación a partir de tres características hermenéuticas fundamentales: el carácter salvífico (DV 11), jerarquizado (UR 11) y analógico (DV 12) de la Palabra revelada.

Palabras clave: tradicionalismo, salvación, relatividad, sentido, analogía.

\section{Abstract}

This article inquieres into the hermeneutics about biblical message, showing the dialectical process between tradicionalism and cultural accomodation of the Word, according to its three fundamental hermeneutical attributes: salvific character (DV 11), hierarchical order of truths (UR11) and analogical meaning (DV12) character of the revealed Word.

Kayword: Biblical language, traditionalism, salvation, analogy, meaning

${ }^{1}$ Doctor en Ciencias de la Religión (Mención Teología Protestante), Universidad de Strasbourg, Francia. Profesor Titular Adjunto de teología fundamental en la Facultad de Teología de la Pontificia Universidad Católica de Chile. Correo electrónico, abentue@uc.cl 
La teología es tan antigua como la fe misma. Es el intellectus fidei, o la fides quaerens intellectum, según la expresión clásica acuñada por San Anselmo²; aunque ya mucho antes San Agustín había desarrollado esa misma perspectiva, advirtiendo que fides non cogitata nulla est quia nemo potest aliquid credere nisi prius cogitaverit ese credendum ${ }^{3}$. Con esto, tanto Agustín como Anselmo prevenían ya del riesgo sobre el que advertirá Mark Twain al caracterizar a los creyentes como personas que "poseyendo la facultad de razonar, no la usan cuando se trata de cuestiones religiosas" 4 .

Pero, para poder comprender razonablemente, hay que interpretar, sobre todo cuando se trata de tradiciones o escritos elaborados en una cultura que, en gran parte, ya no es la nuestra. Por lo mismo, el quehacer que han tenido que asumir los teólogos a lo largo de la historia, marcada por cambios culturales sucesivos, ha sido siempre una tarea hermenéutica, o sea la de interpretar, para poder comprender el sentido razonable de la fe. Es lo que ya aconsejaba la Primera carta de Pedro a los cristianos que, en el mundo gentil, se encontraban con nuevos desafíos culturales: "Estén siempre dispuestos a dar razón (pros apologian) de su esperanza a todo aquel que se lo pida" (1Pe 3,15).

La interpretación teológica más originaria corresponde a la misma presencia del ser humano en el mundo donde Dios no aparece ni habla; y, por lo mismo, el creyente teólogo debe dar razón de ¿por qué Dios tiene que ser, si nunca lo ha visto nadie? ¿Qué indicios permiten interpretar la ausencia o silencio divinos como mensajes que la divinidad da de su existencia? ¿Y cómo se muestra esa presencia del Dios que le habla al ser humano? En nuestro contexto cultural judeo-cristiano, el ser humano ha descubierto tal presencia particularmente en determinadas experiencias del antiguo pueblo de Israel, que con el tiempo se sedimentaron en los Escritos del Antiguo Testamento. Luego, en ese mismo pueblo, tuvo lugar un nuevo acontecimiento centrado en la persona de Jesús de Nazaret, la novedad de cuyo impacto constituyó, para sus discípulos, la clave interpretativa de toda la Escritura veterotestamentaria. Tarea que no resultó nada fácil, como ya les reprochó el Cristo Resucitado a los discípulos de Emaús: “Oh tardos

\footnotetext{
2 SAn Anselmo, Proslogion, BAC, Madrid 1952.

3 "Una fe no razonable deja de ser fe, ya que nadie puede creer en algo, si antes no está convencido de que debe ser creído" en De Praedestinatione sanctorum, II, 5.

${ }^{4}$ Carta III, 1998, Santiago: LOM
} 
de corazón para comprender (=interpretar adecuadamente) lo que ya los profetas habían anunciado sobre el Mesías...Y empezando por Moisés, y siguiendo por todos los profetas, les interpretó lo que decían de El las Escrituras" (Lc 24, 25-28).

Pero, a su vez, esa reinterpretación cristológica del Antiguo Testamento, al ser puesta por escrito en el Nuevo Testamento, enfrentó sus propios problemas que determinaron profundos conflictos hermenéuticos al interior de las comunidades cristianas. Todo el debate judeo-cristiano suscitado por Pablo, y resuelto inicialmente por el primer Concilio de Jerusalén (Hech 15,22-29), es buena expresión de ello. Pero, al interior de las comunidades del mundo gentil surgieron también desavenencias que forzaron la oposición de Pablo a falsas interpretaciones gnósticas, apelando a la clave fundamental de la autenticidad interpretativa o hermenéutica de la fe cristiana: "El amor no pasa jamás. En cambio, desaparecerá el don de hablar en nombre de Dios, cesará el don de expresarse en un lenguaje misterioso y desaparecerá también el don del conocimiento profundo" $(1 \mathrm{C} 13,8)$.

Y Pablo llega a esa conclusión a la luz de lo que significa que Dios se haya identificado con un crucificado, que constituye el criterio hermenéutico fundamental de toda teología cristiana “...porque la locura de Dios es más sabia que los hombres, y la flaqueza de Dios más poderosa que los hombres" $(1 \mathrm{C} 1,25)$. Clave que corresponde a la recogida por Mateo en la tradición sinóptica, con la parábola del juicio final como expresión del criterio interpretativo fundamental para discernir lo que finalmente habrá o no habrá valido la pena decidir en la existencia humana: la decisión misericordiosa (Mt 25, 40ss), con respecto a la cual todo lo demás es relativizado.

\section{El debate hermenéutico}

A partir del momento en que la reinterpretación cristiana de la tradición véterotestamentaria entró de lleno en la cultura helénica, el problema hermenéutico siguió planteándose con fuerza. Las teologías gnósticas, arrianas, docetistas nestorianas o monofisitas y monoteletas, pelagianas y semipelagianas, estuvieron en el centro de los debates, todos ellos debates hermenéuticos. La obra Adversus Haereses, de Ireneo de Lion, o el Peri Arjon de Orígenes, marcan un hito particular en el intento de clarificar los criterios para esos debates. Más tarde, el monje Vicente de Lerins, intenta- 
ría también evitar la dispersión teológica apelando a un criterio básico: la "regula fidei", o "Tradición”, como clave hermenéutica de las fuentes escritas del cristianismo, que debe encontrarse en la transmisión de aquello que ubique, semper et ab omnibus creditum est ${ }^{5}$. Sin embargo, ese criterio es tan amplio que obliga a ir a algo muy de fondo y común para que pueda ser tan universalmente válido. O bien, lo "tradicional" puede interpretarse en forma tan restringida que contituya un criterio incapaz de asumir lo nuevo. Y de hecho así lo explicita el mismo Commonitorium, dando valor normativo único a la fórmula recibida, sin aceptar innovaciones: "Nada debe innovarse,sino que debe observarse siempre lo que ha sido transmitido".

De esta manera, la tensión entre "tradición" e "innovación" pasó a constituir el nudo del problema hermenéutico7. Si el problema se intenta resolver por el lado de la mera tradición, tenemos una hermenéutica "fundamentalista o tradicionalista". Si se intenta resolver por el lado de apertura a la innovación, puede arriesgarse la normatividad de la reinterpretación cristiana originaria y caer en la "relativización" de la norma no normada que es la Revelación bíblica.

Como resultado del impacto de la ilustración moderna, muy concretamente de la Crítica kantiana, se produjo la doble reacción hermenéutica, acentuando uno de esos dos aspectos. Kant, en su "Crítica de la pura razón”, llega a la conclusión de que la razón autónoma sólo puede llegar a afirmar con valor de verdad apodíctica el fenómeno, o sea lo que al sujeto le aparece como verdadero, pero nunca puede saber si eso que le aparece a él (fenómeno) corresponde o no a la realidad en sí (noumenon) ${ }^{8}$. Así, pues, por pura razón, no sabemos nunca si conocemos o no conocemos verdadeII, 5 .

5 "Lo creído en todas partes, por todos y en todos los tiempos", Commonitorium, ${ }^{6}$ Commonitorium, VI.

$7 \mathrm{Al}$ respecto, Cf. la obra clásica de I. CongAR, La tradición y las tradiciones, I. Ensayo Histórico, II. Ensayo teológico, 1964, San Sebastián: Dinor; también puede verse un desarrollo sistemático del concepto católico de Tradición en la obra de J. A. AlCAIn, La Tradición,1998 Bilbao: Universidad de Deusto.

${ }^{8}$ Así expresa: "Por más alto que fuera el grado de claridad que pudiéramos dar a nuestra intuición, nunca nos aproximaríamos a la naturaleza de las cosas en sí; porque en todo caso sólo conoceríamos perfectamente nuestro modo de intuición, es decir nuestra sensibilidad; y esto siempre bajo las condiciones de tiempo y espacio originariamente inherentes en el sujeto. El más perfecto conocimiento de los fenómenos, que es lo único que nos es dado alcanzar, jamás nos proporcionará el conocimiento de los objetos en sí mismos”, en: Estética Trascendental, II n. 8, en Crítica de la razón pura, 1961, Buenos Aires: Sopena. 
ramente la realidad en sí. Y Kant, marcado quizá por su tradición luterana, se refugia en la "crítica de la razón práctica” para recuperar el valor de verdad y la ética universalmente normativa, en un "imperativo categórico", análogo a la sola fides de Lutero. Paradójicamente, la teología protestante postkantiana tomó el camino de la llamada "teología liberal” (Dibelius, Bultmann), la cual pretendía aplicar a la Escritura criterios hermenéuticos relativizadores de su valor de verdad "positiva”, intentando así desvirtuar, con la razón moderna, el valor de la razón histórica en el acceso al evangelio, para retener la "sola fe" identificada con el kerigma interpelador ${ }^{10}$. La exégesis desmitologizadora de la teología liberal protestante alemana provocó la reacción por parte de Karl Barth, con su "teología dialéctica" centrada en el positivismo de la Palabra bíblica, poniendo todo el acento en la irrupción "escatológica" de Dios, que no permite absolutizar ninguna realización mundana ni eclesiástica. Su postura marcó el inicio de la "iglesia confesante" que se enfrentó al intento de legitimación "cristiana” del tercer Reich.

En el ámbito norteamericano, esa misma reacción respecto a la "teología liberal”, aunque totalmente ajena a la "teología escatológica” barthiana, provocó el surgimiento del "fundamentalismo" protestante, representado por Curt Lewis con la publicación de sus doce fascículos titulados The fundamentals: a testimony of the truth, aparecidos entre 1910 y 1915. De ese movimiento derivaría, más tarde, la llamada Moral Majority, iniciada por el ultraconservador Jerry Falwell en 1979, con los tintes propios de un marcado narcisismo norteamericano.

Por parte católica, se produjo también una reacción análoga respecto

9 Y así expresa: "La verdadera religión única no contiene nada más que leyes; esto es, principios prácticos de cuya necesidad incondicionada podemos ser conscientes y que, por lo tanto, reconocemos como revelados, por la pura razón (y no positivamente)...", en: I Kant, La religión dentro de los límites de la mera razón, Alianza Editorial, Madrid 1969, 164.

${ }^{10}$ Es significativo en este sentido la forma con que Bultmann comienza su obra Teología del Nuevo Testamento: "La fe cristiana comienza a existir en el momento en que existe un kerigma; es decir, un kerigma que anuncia a Jesucristo como la acción salvífica escatológica de Dios. Este kerigma es en realidad Jesucristo, el crucificado y resucitado. Esto comenzó a suceder por primera vez en el kerigma de la primitiva comunidad, no ya en la predicación del Jesús histórico, aun cuando la comunidad con frecuencia haya introducido, en la relación sobre la predicación de Jesús, motivos de su propio kerigma”, en: R. Bultmann, Teología del Nuevo Testamento, Sígueme Salamanca 1987, 40. 
a la "teología ilustrada", surgida en diálogo con la primera modernidad, reacción conocida como "integrista" o "tradicionalista". Dado que con la sola razón no podemos saber lo verdadero, y que el mismo uso de la razón lleva a su propia autodestrucción como medio válido para ello, viendo en el mismo Kant ese peligro autodestructor, el tradicionalismo concluye que no podemos fiarnos de la razón, sino sólo de la tradición; o sea, de lo que viene legitimado tradicionalmente, en la "integridad" (de ahí el término "integrismo") de la estructuración social, cognoscitiva y ética, según el prototipo constantiniano y carolingio medieval, y de las formulaciones de fe recibidas desde siempre. Es la hermenéutica tradicionalista asumida en el siglo XIX y principios del siglo XX en muchos sectores católicos, incluso oficiales. El tradicionalismo más radical fundaba esa certeza en los orígenes mismos de la humanidad, cuando Adán y Eva habrían recibido directamente de Dios los valores verdaderos, antes de ser obnubilados por el pecado original. Por lo mismo, aunque ensuciado por ese pecado que afecta a todo lo humano desde sus orígenes, en la naturaleza está inserta la revelación primitiva de los valores absolutos sobre Dios y sobre el hombre y sus deberes morales... Y así, toda innovación que se aparte de lo ahí transmitido, es contraria a la revelación divina. Frente a ese tradicionalismo radical ${ }^{11}$, el Concilio Vaticano I tuvo que reaccionar, valorando el ejercicio de la razón natural con vistas al descubrimiento de la verdad: Dios, principio y fin de todas las cosas, puede ser conocido por la luz natural de la razón humana.

Lo cual permitiría también la autonomía propia de la racionalidad moderna (ciencias) como punto de partida inductivo de esa afirmación de Dios. Sin embargo, el Concilio no deja por ello de condicionar esa razón a lo recibido por Revelación sobrenatural del mismo Dios:

Puesto que plugo a la sabiduría y bondad divina revelar al género humano por otro camino, y éste sobrenatural, a sí mismo y los mismos decretos de su voluntad (normas morales) ${ }^{12}$.

${ }^{11}$ Así, el primer Lamennais apela a la revelación primitiva, de la que derivan los valores morales y de verdad, fuera de lo cual no habría en nosotros "ningún medio para reconocer cuándo nos hemos equivocado. Ninguna regla infalible de lo verdadero. Ello basta para que, -por la sola razón- no podamos rigurosamente afirmar nada, ni nuestra propia existencia”, en: Essai sur L'indifférence en matière de religión, 1820, Paris: Flammarion 29.

${ }_{12}$ Vaticano I, Constitución Dei Filius, cap. 2 (DZS 3004). 
Y no cabe duda que, en el concepto de modernismo asumido por la Encíclica Pascendi de 1907, con la subsiguiente sospecha respecto a todas las innovaciones hermenéuticas de la exégesis bíblica, había una concepción tradicionalista del criterio o regla de la verdad católica recibida. Es lo que más tarde objetó la Encíclica de PíoXII, Divino Afflante Spiritu (1943), saliendo en defensa de los nuevos exégetas católicos:

"Tengan presente todos los hijos de la Iglesia que los conatos de esos valientes operarios de la viña del Señor deben juzgarlos no sólo con justicia y ecuanimidad, sino también con suma caridad, y deben estar muy lejos de ese poco prudente espíritu que juzga que hay que rechazar todo lo nuevo por ser nuevo o tenerlo a lo menos por sospechoso [...] Son muy pocas las cosas cuyo sentido haya sido declarado por la autoridad de la Iglesia, y no son tampoco más aquellas en que unánimemente convienen los Padres. Quedan, pues, muchas y muy graves cosas en cuyo examen y exposición puede y debe ejercitarse libremente el ingenio y la agudeza de los intérpretes católicos"13.

Con lo dicho hasta aquí parece, pues, que el problema hermenéutico no es algo nuevo, sino curiosamente "tradicional". La pregunta que surge ahora es: cómo se reubica actualmente ese problema y qué criterios hermenéuticos, también tradicionales, pueden servirnos para el servicio eclesial de la teología en la actualidad. Esa tarea quiso ya enfrentarla el Concilio Vaticano II, abriéndose al diálogo franco con el mundo moderno, para superar así el grave impasse que seguía pendiente desde los anatemas del Syllabus $(1864)^{14}$.

\section{Hermenéutica y postmodernidad}

Desde los años 60 del Concilio Vaticano II, han ocurrido muchos acontecimientos que encuadran esa modernidad dentro de nuevos aspectos. Se trata de los fenómenos que han determinado el desencanto respecto a las tres grandes utopías modernas (Progreso, Nacionalismo y Socialismo) que

${ }^{13}$ Pío XII, Divino afflante spiritu: sobre el promover oportunamente los estudios de la sagrada Biblia, Ś́gueme, Salamanca 1965, 25. (En adelante DAS).

${ }_{14}$ Los anatemas culminan, en su número 80, con la siguiente advertencia: "Sea anatema si alguien dice que el Romano Pontífice puede o debe reconciliarse y dialogar con el progreso, con el liberalismo y con la civilización moderna” (DZS 2980). 
secularizaban las promesas escatológicas del Cristianismo: con el Progreso, como resultado de la eficiencia científico-técnica, se pensaba superar el problema de la inconsistencia de la vida, dando al hombre una existencia terrena paradisíaca; la utopía de la Nación o la Raza permitiría al individuo desproblematizar su finitud mortal gracias a la pertenencia a una nación o raza inmortal; y la utopía socialista haría posible lograr la igualdad y fraternidad social como resultado de la eficiencia política de la lucha de clases científicamente aplicada. Sin embargo, los acontecimientos del siglo XX fueron minando esas tres utopías, desvirtuándose cada vez con más fuerza sus grandes discursos.

La certeza de un Progreso creciente entró en crisis bajo el impacto de las dos guerras mundiales, las bombas atómicas en Japón y el problema ecológico que amenazan cada vez con mayor gravedad la supervivencia misma del planeta ${ }^{15}$; por otro lado, las barbaridades cometidas en la Alemania nazi o el Japón imperial durante la segunda guerra mundial en nombre de la superioridad de la propia nación o la propia raza, así como después en América Latina los abusos cometidos en nombre de la llamada Doctrina de la Seguridad Nacional ${ }^{16}$, durante las dictaduras militares, fueron minando el valor utópico de la nación o la raza como garantía de inmortalidad grupal, al experimentar una mayor cercanía de la muerte, como consecuencia precisamente de esas ideologías; finalmente, la utopía socialista se vio remecida por la hipocresía que encubría bajo sus grandes discursos altruistas, hasta reventar con la Perestroika y los fracasos de tantas revoluciones que derivaron en nuevas formas de poder al servicio de intereses de grupos, quedando así desprestigiadas.

Como consecuencia de esta triple decepción, surge una nueva situación cultural que suele denominarse postmodernidad, y que recoge las desconfianzas ambientales con respecto a los grandes discursos utópicos. El hombre postmoderno no está ni ahí con ellos y se refugia en la fugacidad de un

${ }^{15}$ Es casi una premonición "profética" la que Freud señaló en Malestar en la cultura, en cuya obra, después de introducir las evidencias que lo llevan a postular, como reprimida en el inconsciente humano, junto a la pulsión de vida o Eros, una segunda pulsión, la de muerte Thanatos, termina su obra con estas palabras: "Sólo nos queda esperar que la otra de ambas 'potencias celestes', el eterno Eros, despliegue sus fuerzas para vencer en la lucha con su no menos inmortal adversario, el Thanatos. Pero ¿̇quién podría augurar cuál será el desenlace final?” en Malestar en la cultura, Obras Completas, 1948, Madrid: Biblioteca Nueva, III, 18.

${ }^{16} \mathrm{Cf}$. Documento del Sínodo de PUEBLA, 547. 
presente leve (light), aunque tal levedad pueda incluso hacérsele insoportable ${ }^{17}$. La postmodernidad renuncia a los grandes discursos tradicionales del pasado y también a las grandes proyecciones utópicas de futuro. Y se conforma con el presente, el ahora y aquí, por banal que pueda resultar. La vida hay que vivirla sin hacerse mayores ilusiones y sin pensarla mucho, con un pensamiento débil, ya que pensar demasiado conlleva el riesgo de desesperar debido a los vacíos de sentido ${ }^{18}$ que pueda implicar ese absurdo. Y puesto que la conciencia del absurdo suscita la angustia, y sólo la conciencia de sentido puede aportar la esperanza de felicidad, cestamos condenados a la infelicidad? O bien, para huir del vacío de sentido que la provoca, ¿no nos queda otra salida que la alienación en un pensamiento débil, refugiándonos en las acciones sucesivas del ahora y aquí? ${ }^{19}$.

Y además esta huida cultural ante los problemas de sentido plantea, de paso, el problema del fundamento ético. Podemos quizá ponernos de acuerdo sobre una ética de minimos ${ }^{20}$, y consensuar también unos sentidos mínimos mútuamente respetados con vistas a la convivencia práctica; pero resultarán siempre pequeños sentidos pragmáticos, de meras formas pactadas incluso democráticamente, sin un fundamento que pueda transcenderlas. D. Hervieu-Léger describe esta situación como la pérdida de la "memoria" que caracteriza a la tradición religiosa semita. Y comenta:

La situación de amnesia que produce, en las sociedades tecnológicamente avanzadas, la dislocación pura y simple de toda memoria que no sea inmediata y funcional, es causa del vaciamiento religioso ${ }^{21}$.

En ese contexto resulta difícil acordar una hermenéutica convincente, que dé sentido a lo que creemos, puesto que a la cultura light le bastan razones meramente pragmáticas, asumiendo la forma que sea, mientras

${ }^{17}$ Cf. M. Kundera, La insoportable levedad del ser, Tusquets, Barcelona 1984.

18 Expresiones acuñadas por el teórico de la postmodernidad G. VATTIMO, Il pensiero debole, 1983, Milan: Feltrinelli.

${ }^{19}$ El mismo Nietzsche, considerado por algunos como el padre del pensamiento "postmoderno", advertía sobre el riesgo de esa "huida en la acción no pensada": "Por falta de sosiego, nuestra civilización desemboca en una nueva barbarie. En ninguna época se han cotizado más los activos, es decir, los desasosegados. Cuéntase, por tanto, entre las correcciones necesarias, que deben hacérsele al carácter de la humanidad, el fortalecimiento en amplia medida del elemento contemplativo", en Humano, demasiado humano, Akal, Madrid 2007, 180.

${ }_{20}$ Concepto elaborado especialmente por A. CoRTINA, en Ética mínima: Introducción a la filosofía práctica, Tecnos, Madrid 1986.

${ }^{21}$ Cf. D. Hervieu-LÉGER, La religion pour mémoire, Du Cerf, Paris 1993, 203. 
funcionen, prescindiendo de que tengan o no sentido de acuerdo a lo que pudiera postular un pensamiento fuerte, ajeno al ambiente cultural del medio. Si bien, después de postular un a ética de mínimos, tengamos el riesgo de que, habiendo descartado la transcendencia, podamos quedar sumidos en la intranscendencia, es decir en la banalidad...como resaca destructiva del abandono de la transcendencia ${ }^{22}$. Resaca Que ya señalaba Nietzsche en las expresiones puestas en boca del loco que buscaba a Dios en pleno mercado y a pleno día, con una linterna en la mano, mientras muchos representantes de la muerte de Dios no cesaban de reírse. Pero él les gritaba.

¿Dónde se ha ido Dios?, voy a decírselo: iNosotros lo hemos matado! Somos sus asesinos. Pero ¿̇cómo hemos podido hacerlo? ¿Cómo pudimos vaciar el mar? ¿Quién nos dio la esponja capaz de borrar todo el horizonte? ¿Qué hicimos al desatar la tierra de su sol? ¿Hacia dónde va ahora? ¿A dónde vamos alejándonos de todos los soles? ¿No estamos cayendo continuamente, hacia atrás, hacia delante, hacia todos los lados? ¿O es que existe todavía un arriba y abajo? ¿No estamos vagando a través de una nada infinita? ¿No cae constantemente la noche y cada vez más oscura, que haga preciso encender las lámparas en pleno día? ¿No oímos aún nada del ruido de los sepultureros que entierran a Dios? ¿No percibimos todavía la podredumbre divina? iPues los dioses también se pudren! iDios ha muerto! iDios sigue muerto! Y nosotros lo hemos matado ${ }^{23}$.

Y es quizá esa misma sensación de banalidad la que explica el boom religioso del politeísmo light característico de la postmodernidad, con la proliferación de todo tipo de movimientos en competencia, como un intento desesperado de llenar el vacío producido por el olvido de los criterios fundantes de Sentido, como consecuencia de la muerte cultural de Dios. El mismo Vaticano II asumió con indudable coraje la propia responsabilidad en el origen del reduccionismo ateo, al reconocer:

"En la génesis del ateísmo pueden tener parte no pequeña los propios creyentes, en cuanto que, con el descuido de la educación religiosa, o con la presentación inadecuada de la doctrina o incluso con los defectos de su vida religiosa, moral y social, han velado, en lugar de revelado, el genuino rostro de Dios y de la religión”"24.

\footnotetext{
${ }^{22}$ F. SABATER, Ética como amor propio, Mondadori, Madrid 1988, 312.

${ }^{23}$ NIETzsche F., La Gaya ciencia, Fontamara, 1966 México, 163.

${ }^{24}$ GS 19.
} 
Esta fuerte advertencia, obliga a una adecuada hermenéutica sobre el verdadero sentido de la tradición creyente que sustenta a la Iglesia, llamándola a su deber evangelizador, que implica la inculturación de la fe y no la mera inercia transmisora. Para ello, el mismo Concilio hace un poderoso llamado a inculturar la fe católica en la nueva cosmovisión moderna, discerniendo en ella los signos de los tiempos, como presencia interpeladora del Espíritu de Dios en medio de la ambigüedad propia de todo lo humano:

El pueblo de Dios, movido por la fe que lo impulsa a creer que quien lo conduce es el Espíritu del Señor, que llena el universo, procura discernir en los acontecimientos, exigencias y deseos, de los cuales participa juntamente con sus contemporáneos, los signos verdaderos de la presencia o del plan de Dios"25.

Y tal requerimiento de atención a los signos de los tiempos no es por la necesidad que tiene la Iglesia de estar al día, sino por fidelidad al sentido salvífico de su misión como transmisora de la Palabra. Es por eso que:

“... la adaptación de la predicación de la Palabra revelada debe seguir siendo la norma de toda evangelización. Pues así se hace posible, en toda nación, expresar el mensaje de Cristo a su modo y, al mismo tiempo, se promueve un intercambio vital entre la Iglesia y las culturas diversas de los pueblos. Para aumentar ese intercambio, la Iglesia, sobre todo en nuestros tiempos en que tan rápidamente cambian las cosas y tanto varían los modos de pensar, necesita de modo particular la ayuda de quienes viven en el mundo, conocen sus diversas instituciones y disciplinas y asimilan su mentalidad, sean creyentes o no"26.

Y consecuente con ese llamado del Espíritu, señala la tarea para la misma Iglesia en sus diversas instancias:

Es propio de todo el Pueblo de Dios, aunque principalmente de los pastores y teólogos, auscultar, discernir e interpretar, con la ayuda del Espíritu Santo, las múltiples voces de nuestro tiempo y valorarlas a la luz de la Palabra divina, a fin de que la verdad revelada pueda ser mejor percibida, mejor entendida y expresada en forma más adecuada ${ }^{27}$.

Se trata, pues, de la labor hermenéutica que compete al Pueblo de Dios y, dentro de él, al servicio teológico.

${ }^{25}$ GS 11.

${ }^{26}$ GS 44.

${ }^{27} \mathrm{GS} 44$. 


\section{Tres claves hermenéuticas fundamentales}

1. Primero, la clave salvífica, recogida en forma explícita en el texto de Dei Verbum: Scripturae libri veritatem quandam Deus 'nostrae salutis' causa...consignari voluit ${ }^{28}$. La razón de ser de la Palabra es, pues, que el ser humano experimente su impacto salvífico, sin que pretenda con ello interferir en la autonomía de los conocimientos científicos que él mismo pueda ir descubriendo. Para explicitar esta perspectiva, según la cual la Palabra no pretende tanto informar, sino salvar, el mismo texto conciliar remite, en nota, al comentario de San Agustín sobre el Génesis que, siendo ad litteram, es de acuerdo a la intención salvífica de la Palabra, puesto que "el Espíritu de Dios, que hablaba por su boca, no ha querido enseñar a los hombres estas verdades concernientes a la constitución íntima de los objetos visibles, porque ellas no debían servirles de nada para su salvación”29. Así, pues, la Biblia no puede ser usada para justificar contradicciones respecto a las nuevas evidencias científicas y, por lo mismo, la teología y la misma Iglesia deben dejar definitivamente atrás el tipo de penosa controversia entre el Magisterio y Galileo Galilei ${ }^{30}$, que dio pie a tantos conflictos ulteriores entre la Iglesia y el mundo moderno. Aunque, como vimos anteriormente, ese enfrentamiento fue en buena parte superado ya con la Encíclica de Pí XII, Divino Afflante Spiritu (1943).

Decir que la Palabra tiene por objeto nuestra salvación, constituye, por lo demás, el objetivo de todas las formulaciones del Credo, puesto que expresan que la voluntad eterna de Dios, así revelada, es propter nostram salutem. DV 11.

28 "Los libros de la Escritura que Dios quiso consignar por nuestra salvación”,

${ }^{29}$ Agustín, De Genesi ad litteram, II, 9,20.

3o Tal como muestra el texto que Galileo tuvo que firmar para evitar la condena del Vaticano: "Como este Santo Oficio me había jurídicamente conjurado a abandonar del todo la falsa opinión que afirma que el sol es el centro y es inmóvil y que yo no podía sostenerla ni defenderla, ni enseñarla de ninguna manera, en forma oral o escrita, y como después que me fue dicho que la susodicha doctrina era contraria a la Sagrada Escritura, he escrito y hecho imprimir un libro que trata de esta doctrina condenada y aporta razones de gran eficacia en favor de tal doctrina sin agregar ninguna solución, es por todo eso que he sido juzgado gravemente de herejía, por haber sostenido y creído que el sol era el centro del mundo y que era inmóvil, y la tierra no era el centro y se movía...", en BubleInikov F.D., Galileo Galilei , Col. ABC Tecnociencia, Montevideo 1964, 2-3. 
Sin embargo, nuestra cultura secularizada ha perdido, en gran medida, el interés por lo que el término teológico de salvación pueda significar. Debido a la misma capacidad de autonomía, propia de la cultura científicotécnica, muchos se preguntan hoy isalvarnos de qué?. Y esa misma pregunta refleja ya precisamente la situación cultural de vacíos de sentido a la que antes aludimos. Nuestra cultura ambiental tiende a concentrar las razones para vivir en el consumismo que permite sensaciones, a menudo frenéticas, de placer. $\mathrm{Y}$ cuando el objeto de consumo es particularmente ostentoso y caro, el placer va asociado también a la sensación de poder y de riqueza. Placer, poder y riqueza, son así las características de nuestra cultura valórica consumista y hedonista ${ }^{31}$. Aunque siempre han estado presentes en la historia humana como las tres tentaciones que la primera carta de Juan identifica en las tres epithümiai, que no vienen del Padre, sino del mundo: la concupiscencia de la carne (epithümia tes sarkós), la ambición del poder (epithümia ton ofthalmón) y la vanagloria de la riqueza en la vida (alatsoneia tou biou) (1 Jn 2,16). A esas mismas tres concupiscencias, como supuestos criterios del valor del ser humano en el mundo, remiten los tres tipos de falsos valores, cuya relativización marca el camino de la Felicidad: Felices (makarioi) quienes toman conciencia de que el criterio de Felicidad no radica en el placer (felices los que pasan hambre, pasan sed, lloran y son puros), ni en el poder (felices quienes son mansos, pacíficos y perseguidos), o en la riqueza (felices los pobres) (Mt 5,4-10). Aun cuando no se trata con ello de proponer una visión dualista de la existencia humana, que considera como un mal el placer, el poder o la riqueza. Lo que propone el evangelio es la relativización de esos criterios, situándoles realmente en relación a lo que constituye el valor absoluto: el Reino de Dios, comprendido como el fundamento de sentido de la existencia que, como tal, hace feliz, superando el riesgo de absurdo cuya conciencia es la angustia $^{32}$. Son felices quienes han descubierto ese Reino de sentido y, motivados

${ }^{31}$ Aun cuando el "hedonismo" postmoderno se sostiene sobre criterios más pragmáticos y sensoriales que filosóficos, pueden encontrarse antecedentes filosóficos en pensadores de la antigüedad griega, particularmente en Aristipo de Cirene. Respecto a ello, remito a la obra reciente de LAMPE Kurt, The Birth of Hedonism. The Cyrenaic Philosophers and the Pleasure as a Way of Life, Princeton University Press, New Jersey 2015,

${ }^{32}$ Cf. Heidegger, M. Ser y Tiempo, Ed. Universitaria (trad.de Jorge Eduardo Rivera), Santiago 1997, 209. 
por la felicidad de ese descubrimiento (Mt 13, 44-46), deciden libremente seguir ese camino, desapegándose de los estímulos esclavizantes ${ }^{33}$.

El impacto cultural de los medios de comunicación social ha situado ante los ojos de la gente el atractivo de la vida de protagonistas, reales o ficticios, como los "hombres o mujeres de mundo", convirtiéndoles en ideales, particularmente para la juventud, de acuerdo al prototipo de sociedad según el modelo neoliberal capitalista. Un modelo de ser humano pretendidamente libre, aunque poniendo su libertad al servicio del ansia de producción y de consumo, para lograr aquellos mismos ideales, aun cuando llevan a la sociedad a convertirse en una "sociedad del cansancio" 34 , debido a que el ser humano pierde así contacto con los fundamentos del sentido de la vida:

"Frente a la vida desnuda, convertida en algo totalmente efímero, reacciona justo con mecanismos como la hiperactividad, la histeria del trabajo y la producción. También la actual aceleración está ligada a la falta de ser. La sociedad de trabajo y rendimiento no es ninguna sociedad libre...En esta sociedad de obligación, cada cual lleva consigo su campo de trabajos forzados...Así, uno se explota a sí mismo, haciendo posible la explotación sin límite... La sociedad del rendimiento es una sociedad de auto-explotación. El sujeto, obligado a aportar rendimientos, se explota a si mismo hasta quemarse del todo. En ello se desarrolla una auto-agresividad que no rara vez recrudece hasta llegar al suicidio" 35 .

Es, pues, desde el corazón de esta sociedad, que la Palabra salvación, vaciada hoy de sentido, puede retomar su verdadero significado propter nostram salutem. Ese sentido remite a experiencias propias de la conciencia humana al descubrir una buena noticia que le impacta de forma tanto más convincente cuanto más le permite abrirse a la esperanza, en un mun-

${ }^{33}$ Análogamente al descubrimiento hecho por Siddarta Gautama al experimentar la "iluminación" que lo constituyó en el Buda, cuando hubo tomado conciencia de las causas del sufrimiento y el camino de su superación, expresado con las cuatro nobles verdades: primera, existir es sufrir; segunda, la raíz del sufrimiento es el deseo; tercera, para dejar de sufrir hay que dejar de desea; y cuarta, los ocho caminos (yogas) del desapego, cf. BENTUE A. Dios y dioses. Historia religiosa del hombre, Ed. PUC, Santiago 2004, 87-88 y 318-319.

${ }^{34}$ Cf. H. ByunG-Chul, La sociedad del cansancio, Herder, Barcelona 2017.

35 H. Byung-Chul, La sociedad..., 96. 
do amenazado de inconsistencia y aniquilación ${ }^{36}$. Debe ser, por lo mismo, un sentido motivador de la propia libertad, que pueda hacernos realmente libres al liberarnos, es decir salvarnos, de la esclavitud del trabajo explotador con vistas al consumismo inhumano. En una cultura marcada así por los vacíos de sentido, la Palabra evangelizadora tiene que ser descubierta como convincente por el sentido que aporta a la propia existencia. Tal como lo expresaban los obispos, de forma casi profética, al final del Concilio: "El porvenir de la humanidad está en manos de quienes sepan dar a las generaciones futuras razones para vivir y razones para esperar" ${ }^{37}$. Es decir, Sentido. Y lo retomará después el Magisterio de Puebla al expresar: "El sentido último de la existencia radica en aquella zona más profunda, donde el ser humano encuentra respuestas a las preguntas básicas y definitivas que lo acosan..." ${ }^{8}$.

La transmisión de esa Palabra no puede prestarse a identificar, con su verdadero sentido, un conjunto de fórmulas dogmáticas, presentadas en un pensamiento culturalmente ajeno al receptor, más aún si le resultan sospechosas de intereses de poder.

La Palabra no pretende informar o dominar, sino salvar. La experiencia salvífica supone, pues, descubrir la profunda correlación entre la interpretación de la Escritura y la propia situación vital. Tal como lo expresaba la genialidad exegética de Orígenes:

"Si tengo necesidad de la Escritura para comprenderme, también comprendo la Escritura cuando la leo en mí mismo... A medida que penetro en su sentido, la Escritura me hace penetrar en el sentido último de mi ser; ella es así el signo que me revela mi alma. Pero también la recíproca es verdadera: La una sirve de reactivo a la otra. Cada vez que soy fiel al

${ }^{36}$ Es significativa, todavía hoy, la obra del joven autor alemán MAINLÁNDER PH., Filosofía de la Redención. Antología, 2011, Santiago de Chile: Fondo de Cultura Económica, (Ed. Sandra Baquedano). En dos volúmenes, el autor desarrolla su tesis sobre la intencionalidad divina que funda el cosmos a fin de que toda la vida que ahí surja tenga como orientación final la aniquilación: "El universo es un acto unitario...y permanece por eso en una conexión dinámica insoluble, a partir de la cual surge un movimiento unitario: es el movimiento hacia la aniquilación completa, el movimiento del ser hacia el no-ser", Coherente con esa tesis, e identificando la aniquilación completa con lo que él denomina redención, o salvación final, el mismo día 1 de abril de 1876 en que Mainländer recibió el último volumen editado de su obra, se suicidó.

37 GS 31.

${ }^{38}$ Documento de Puebla, 389. 
Espíritu de Dios en la interpretación de las Escrituras, mi interpretación es válida..." 39 .

Un modelo notable de esa primera clave hermenéutica lo constituye el trabajo misionero de Fray Bartolomé de las Casas, con su notable obra De único vocationis modo omnium Gentium ad veram religionem ${ }^{40}$, en que sintetiza esa primera clave fundamental de toda labor teológica:

"Queda, pues, de manifiesto que la voluntad para mover al entendimiento de aquel que ha de ser instruido en la fe y la verdadera religión, para que preste su asentimiento y adhesión a las cosas de esa fe y religión, se atrae, se estimula e inclina de un modo delicado y suave, con libre albedrío, más aún, con gusto, placer y amor. Por consiguiente, es verdadero y muy verdadero que la norma para enseñar y encaminar o atraer a la fe y la religión cristiana a quienes están fuera de ella ha de ser persuasiva del entendimiento y atractiva, excitativa y exhortativa de la voluntad"41.

Tal correlación salvífica entre Palabra de Dios y existencia humana ha sido desarrollada después por grandes teólogos, sirviéndose incluso de elementos filosóficos extraídos de la fenomenología existencial heideggeriana ${ }^{42}$. En esa línea destaco también parte de un discurso de Juan Pablo II, dirigido a los teólogos de la Universidad de Salamanca, en que expresaba:

"Si la teología siempre ha necesitado de la filosofía, hoy esa filosofía deberá ser antropológica; es decir, deberá buscar en las estructuras esenciales de la existencia humana, las dimensiones transcendentes que constituyen la capacidad radical del hombre para ser interpelado por el mensaje cristiano al comprenderlo como salvífico, o sea como respuesta de plenitud gratuita a las cuestiones fundamentales de la vida humana. Este fue el proceso de reflexión teológica seguido por el Concilio Vaticano II en la Constitución Gaudium et Spes: la correlación entre los problemas profundos y decisivos del hombre y la nueva luz que irradia sobre ellos la persona y el mensaje de Jesús ${ }^{43}$.

Pero ¿cuáles son esas estructuras esenciales, o dimensiones trascendentes, de la existencia humana? ¿Y cuál es el nivel del problema al que se

${ }^{39}$ Comentario de H. LubAc, Histoire et esprit: l'intelligence de l'écriture d'après Origène, Du Cerf, Paris 1950, 348.

${ }_{40}$ Norma única para invitar a todas las gentes a la verdadera religión, en: B. LAS CASAS, Obras Completas, II Alianza Editorial, Madrid 1990.

${ }^{41}$ B. Las Casas, Obras..., 35.

${ }^{42}$ El más clásico es P. Tillich, Theologie Sistématique, I, Du Cerf, Paris 1991, 32. ${ }^{43}$ Ecclesia, 6 de noviembre, (1982) 3. 
refieren, desde el cual pueda ser razonable postular o intuir salvación? En definitiva, son tres las coordenadas fundamentales de la misma existencia experimentadas como problemáticas, de las que ya hablamos anteriormente: a/ la muerte, b/ la vida y c/ la convivencia.

a/ Aunque sea el último acontecimiento para cada viviente, la muerte se convierte en el primer problema para el ser humano, debido a su capacidad de anticiparla por la conciencia, que puede, así, angustiarle la vida. Debido a ello tendemos a enajenar esa conciencia, convirtiendo la muerte en noticia, de manera que siempre mueren los demás. O también, reducimos teóricamente la muerte a algo que no nos afecta, tal como lo expresaba el antiguo Laercio:

"El más horrible de los males, la muerte, en realidad no nos atañe. Pues, mientras existimos no hay muerte, y cuando habría muerte para nosotros, ya no existimos. Luego, no atañe ni a vivos ni a muertos, a los primeros no los toca y los segundos ya no existen ${ }^{44}$.

$\mathrm{O}$ aún, pretendemos identificarnos con nuestro propio $\mathrm{ADN}, 45$, o bien con el Género humano ${ }^{46}$, participando así de su secuencia inmortal. Pero yo no soy ni mi ADN ni el Género Humano. Y con la evidencia de que cada uno de los individuos muere, puede uno concluir que de la suma de muertes no podrá nunca resultar inmortalidad. Experimentamos la muerte humana siempre como el fin de la existencia de un "tú", en relación a quien sentimos la inevitable angustia por la cercanía del ser querido ${ }^{47}$. Y, al mismo tiempo, experimentamos en ella que yo en cuanto yo dejaré también de ser yo.

44 Cf. Diógenes LAercio, vida y opiniones de los filósofos, Alianza Editorial, Madrid 2013,X, 124 .

${ }_{45}$ Cf. M. BURNETT, "Es literalmente cierto que las moléculas diseñadas por el ADN proceden, en una secuencia inmortal que no se ha roto nunca desde hace 3 mil millones de años, del microorganismo único del cual el código genético universal tomó su forma definitiva. En ese sentido, la vida es inmortal...", en The endurence of Life: The implications of Genetics for human life,1978, Londres: Cambrige University Press, 7.

${ }_{46}$ Cf. L. Feuerbach, La esencia del Cristianismo,1975, Salamanca: Sígueme. Aun cuando el mismo Marx criticó a Feuerbach esa pretendida identificación teórica de los atributos de inmortalidad del Género humano con la realidad mortal de cada individuo, objetándole: "Lo que han hecho hasta ahora los filósofos es interpretar el mundo; pero lo que hay que hacer es cambiarlo", en: Tesis sobre Feuerbach, 1848 (Tesis 11).

${ }_{47}$ Cf. D. Von Hildebrand, "Quien nunca en su vida ha amado, quien nunca realmente ha regalado su corazón a otra persona, nada sabe del horror abismal de la muerte que se abre ante nosotros con la muerte del ser querido", en Sobre la muerte, 1983, Madrid: Ediciones. Encuentro, 20. 
b/ El problema radical de la vida es la inconsistencia. Un proceso de facticidad sin fondo, que constituye el concepto de maya en el hinduis$\mathrm{mo}^{48}$, o de apariencia, tal como lo concibe la filosofía griega ${ }^{49}$. Esa apariencia engañosa determina el concepto griego de verdad como a-letheia, (descubrimiento). Para lograr la verdad hay que ir más allá de lo que aparece, puesto que las apariencias engañan. Pero la cultura moderna y postmoderna tiende a considerar la realidad que aparece como la única realidad, sin que haya un fondo verdadero, más allá de las múltiples formas cambiantes propias de la facticidad misma. De esta manera, lo que aparece coincide con lo único que es. El ser se reduce al mundo fenoménico que aparece. Aun cuando ya Aristóteles había rechazado esta postura reduccionista de algunos filósofos anteriores a él ${ }^{50}$, esa es también la perspectiva propia del Positivismo moderno, agudizada en la postmodernidad debido al derrumbe de las utopías modernas, que radicaliza aún más la insoportable experiencia de la levedad del ser ${ }^{51}$.

c/ Finalmente está el problema de la convivencia, cuyo fundamento radica en la selección natural como ley de la naturaleza, que se replica, en el mundo cultural humano, con la ley de la competencia entre individuos y entre grupos, derivando en los peores escándalos de discriminación y abandono que desangran a nuestra sociedad a lo largo y ancho del planeta.

Es en correlación a esos tres niveles radicalmente problemáticos de la existencia humana que la Palabra puede y debe cobrar un sentido convincente para toda conciencia angustiada por la amenaza de absurdo que conlleva la existencia consciente. Desde esa misma perspectiva cobran especial significado, por un lado, las tres promesas que constituyen el hilo conductor de toda la Biblia ${ }^{52}$ : la Tierra (Vida), la Descendencia (Inmortalidad) y

48 "Lo irreal (Maia) nunca es. Lo real (Sat) nunca deja de ser. Esta verdad la han visto quienes realmente ven lo verdadero" en: BHAGAVAD GITA, II,16.

${ }^{49}$ Cf. ARISTÓTELES, La apariencia no es la verdad, en Metafísica, libro IV, 5.

50 "Este espacio que nos rodea, el lugar de los objetos sensibles, único que está sometido a las leyes de la destrucción y de la producción, no es más que una porción nula, por así decirlo, del universo. De suerte que hubiera sido más justo absolver a este bajo mundo en favor del mundo celeste, que condenar el mundo celeste a causa del primero", en Metafísica, $I V$, 5 .

${ }^{51}$ Esa expresión, acuñada en la famosa novela de Milan Kundera, La insoportable levedad del ser, remite también al concepto heideggeriano de in-hospitalidad (unheimlichkeit), o de carencia de hogar (nicht zu Hause), sentimientos experimentados en la vida humana (Ser y Tiempo, 212).

${ }^{2}$ BENTUÉ A., La experiencia bíblica: Gracia y ética, PPC, Madrid 1997. 
la Alianza (común unión). Y, por otro lado, es en profunda correlación salvífica a los mismos niveles problemáticos de la existencia humana ${ }^{53}$, que ofrece, en respuesta, el triple anuncio de la Palabra revelada y celebrada en los tres misterios centrales del Cristianismo: Navidad, Pascua y Pentecostés. Por la Encarnación, Dios se hace hombre para que el ser humano pueda recibir gratuitamente la consistencia propia de la Vida divina; por la Pascua, Dios muere para que el ser humano pueda abrirse a la Esperanza de Resurrección inmortal;, y en Pentecostés, Dios irrumpe en medio de nuestros desencuentros y confrontaciones, simbolizados por el derrumbe de la torre de Babel, para introducir dentro de nosotros su propio Espíritu de Amor, dándonos así la Esperanza de superación de los egocentrismos.

\section{Una segunda clave hermenéutica del quehacer teológico es la relatividad.}

Así como el mismo Concilio confiesa la responsabilidad de los creyentes en la génesis del ateísmo ${ }^{54}$, deberíamos preguntarnos si la crisis relativizadora de los valores, propia de nuestra época, no se debe también, en buena parte, a una reacción contra el abuso absolutista de un magisterio teológico demasiado centrado en transmitir la seguridad de las fórmulas dogmáticas.

Contra ese riesgo absolutizador, el mismo Concilio, en su llamado al diálogo interreligioso y ecuménico, señala ese criterio relativizador de las formulaciones de la fe: $\mathrm{Al}$ confrontar las doctrinas, no olviden que hay un orden o jerarquía de las verdades en la doctrina católica, por ser diversa su conexión con el fundamento de la fe cristiana ${ }^{55}$.

Los dogmas definidos, aun cuando, para la fe católica, sean considerados como infalibles, deben ser jerarquizados en relación al fundamento cristológico de nuestra fe cristiana común con las iglesias no católicas. Y esa jerarquización resulta también fundamental en el proceso pastoral de la transmisión de la fe católica, en la línea pedagógica de la misma transmisión del mensaje bíblico desde el Antiguo al Nuevo Testamento, con el pa-

53 Cf. Documento de Santo Domingo, 230.

54 Cf. GS 19.

55 Unitatis redintegratio (UR) 11. 
ciente respeto a los procesos que requieren tiempo para su desarrollo y descubrimiento pleno ${ }^{56}$. Tal como lo expresaba Pablo VI, en un texto notable: "El pensamiento humano se mueve hacia adelante... Por dialéctica, de una verdad infiere otra; confrontada por la realidad, que le da una certeza inicial, pero que está llena de complejidades, inclina su mente ya sea a uno de sus aspectos, ya sea a otro. Así se desenvuelve el pensamiento. El curso de su evolución puede trazarse en la historia. Ha llegado el tiempo, creemos, en que la verdad con respecto a la Iglesia de Cristo exige un examen más íntimo, una reflexión más profunda y una expresión mejor" ${ }^{57}$.

La conciencia de esa relatividad de las formulaciones dogmáticas, en relación al fundamento de la fe cristiana, exige actitudes coherentes con ello también en la pastoral, como lo destaca el Papa Francisco:

"La centralidad del kerigma demanda ciertas características del anuncio que hoy son necesarias en todas partes: que exprese el amor salvífico de Dios, previo a la obligación moral y religiosa, que no imponga la verdad y que apele a la libertad, que posea unas notas de alegría, estímulo, vitalidad y una integralidad armoniosa que no reduzca la predicación a unas pocas doctrinas, a veces más filosóficas que evangélicas. Esto exige al evangelizador ciertas actitudes que ayuden a acoger mejor el anuncio: cercanía, apertura al diálogo, paciencia, acogida cordial que no condena" 58 .

3. Finalmente, está la clave propia del carácter analógico de todo el lenguaje de la fe y, por lo mismo, de la teología. Y radica precisamente en la conciencia de que lo único absoluto sólo puede constituirlo la Realidad misma de Dios, que impulsa a la necesaria relativización de todas las formulaciones que intenten expresarlo. Por ello el mismo Catecismo, antes de comenzar la detallada presentación catequética de las fórmulas dogmáticas del Credo, advierte:

${ }^{56}$ Tal como lo expresaba el Cardenal Newman: "el tiempo es necesario para el desarrollo de las grandes ideas”, en: Ensayo sobre el desarrollo de la doctrina cristiana, Londres, 1845 .

57 Discurso de re-apertura del Concilio Vaticano II, en Acta Apostolicae Sedis, 55 (1963) 848.

${ }^{8}$ FrancISCO, Evangelii Gaudium, 165. 
"No creemos en las fórmulas, sino en la Realidad que estas fórmulas quieren expresar y que la fe nos permite 'tocar". Puesto que el acto de fe del creyente no termina en los enunciados, sino en las Realidades (enunciadas). Pero llegamos a encontrar esas realidades a través de las formulaciones de la fe, que nos permiten expresarla y transmitirla, celebrarla en comunidad, asimilarla y vivirla cada vez más"59.

La distinción fundamental entre la Realidad creída y las fórmulas, que buscan orientarnos hacia ella, permite que la fe no confunda nuestras imágenes de Dios con su Realidad, en relación a la cual aquellas fórmulas valen sólo como mediaciones necesarias, y no como formulaciones absolutas en sí mismas. Esta temática fue abordada ya por Santo Tomás, en la cuestión De divinis nominibus, de la Suma Teológica. Y, a partir de la alternativa entre el valor unívoco o equívoco de los enunciados sobre lo divino, señala la inadecuación de las ideas unívocas para referirse a Dios. Lo cual constituiría un lenguaje idolátrico, al aplicar a Dios nuestras propias imágenes sobre él, sacadas siempre inductivamente de la experiencia mundana. Pero, si no pueden ser unívocos los conceptos teológicos, entonces Tomás se pregunta: Utrum de Deo et creaturis omnia praedicentur aequivoce? $\mathrm{Y}$ responde que son equívocos; pero, después de reconocer esa equivocidad, agrega: non pure aequivoce, sed per analogiam ${ }^{60}$. Analogía que, en todo caso, es más cercana a la equivocidad que a la univocidad. Puesto que, entre lo que decimos de Dios y lo que El pueda ser en su Realidad Trascendente, siempre es más la diferencia que la semejanza ${ }^{61}$. Y esa afirmación relativizadora, en lugar de incitar al desinterés niahista respecto al Dios oculto sobre lo que ya advertía el profeta Isaías (Is 45,15), como lo hará después San Juan (Jn 1,18; 1Jn 4,12), abre más bien el corazón humano al silencio de la plegaria contemplativa en la que culmina toda la teología negativa. Como lo expresa con profundidad el mismo Tomás de Aquino:

"Cuando subimos hacia Dios por la vía de la negación... el espíritu se encuentra finalmente en una especie de oscuridad y de ignorancia. Y es

${ }^{59}$ Cf. Catecismo de la Iglesia Católica, 170.

${ }^{60}$ Tomás, Summa Theologica. I, q. 13, ar.5.

${ }^{61}$ Según la formulación del Concilio IV de Letrán "Inter Creatorem et creaturam non potest tanta similitudo notari quin inter eos maior sit dissimilitudo notanda", DZS 806. 
precisamente con esta ignorancia, propia de un ser que está en camino, como estamos más unidos a Dios"62.

Quizá es por ello que el discurso teológico debe ser, en definitiva, un llamado profundo al verdadero silencio, puesto que sobre lo que no se puede hablar, hay que callar63. En forma similar, comentando el texto del profeta Isaías que dice: Israel, en verdad tu Dios es un Dios oculto $(45,15)$, el filósofo Blas Pascal comenta:

"Así, pues, estando Dios oculto, ninguna religión que no nos diga que Dios está oculto es verdadera y ninguna teología que no dé razón de esto es instructiva. Eso es todo para nosotros, Vere Tu es Deus absconditus... Pero la naturaleza es tal que por todas partes nos indica (con indicios) a un Dios oculto, tanto en el hombre como fuera del hombre" ${ }^{64}$.

\section{La experiencia numinosa}

Los indicios a que alude Pascal, podríamos encontrarlos en aquellas características fundamentales de toda experiencia religiosa que Rudolph Otto describe como lo Numinosum, con sus sentimientos concomitantes del Tremendum Mysterium y Fascinans ${ }^{65}$.

Con el neologismo numinoso, Otto intenta expresar el sentimiento más profundo de esa experiencia religiosa, remitiendo a Schleiermacher, quien había expresado el sentimiento religioso fundamental como un "sentimiento de dependencia" respecto al Absoluto divino. Si bien Otto considera que ese sentimiento "no es más que la sombra del sentimiento numinoso, pero no este mismo". Puesto, que, según Otto, Schleiermacher "no se percató de que el nombre 'sentimiento de dependencia' sólo es una aproximación por analogía al verdadero sentimiento que quería definir" y que Otto describe como "sentimiento de creaturidad o numinoso". Y precisa:

\footnotetext{
${ }^{62}$ I Sententiae, Dist. VIII, q.1,a.3 ad 4m. "Desde la tradición budista encontramos textos en esa misma línea, como la descripción negativa con que el Buda intenta decir lo indecible, del Nirvana: Hay, oh monjes, algo no nacido, no originado, no creado, no compuesto. Si no hubiese, oh monges, algo no nacido, no originado, no creado, no compuesto, no habría tampoco posibilidad de liberarse de todo aquello que es nacido, originado, creado y compuesto. Pero como que hay, oh monges, algo no nacido, no originado, no creado y no compuesto, hay, por tanto, posibilidad de liberarse de todo lo que es nacido, originado, creado y compuesto", en: UdANA, La palabra de Buda, Buenos Aires: Trotta, 8,3.

${ }_{63}$ L. WitTGENSTEIN, Tractatus lógico-philosophicus, 1981, Barcelona: Laia, n.7.

${ }^{64}$ B. PASCAL, Pensées, 1976, Paris: Flammarion, VIII y XIV, 585 y 876.

${ }^{65}$ R. OTTO, Lo Santo. Lo racional y lo irracionla en la idea de Dios, 1985, Madrid: Alianza Editorial.
} 
"El sentimiento religioso sería inmediatamente y desde luego un sentimiento de 'mí mismo', el condicionamiento de una peculiar condición mía, a saber, de mi dependencia. ...En cambio, el sentimiento de criatura es más bien un momento concomitante, un efecto subjetivo, por decirlo así, la sombra de otro sentimiento, el cual, desde luego, y por modo inmediato, se refiere a un objeto fuera de mí. Y es este precisamente al que denomino lo numinoso...Sólo por el uso de la categoría de numinoso, puede engendrarse en el ánimo el sentimiento de criatura, como un sentimiento concomitante"66.

En su análisis de la experiencia religiosa, Otto distingue los sentimientos, que hacen referencia al mismo sujeto que los experimenta, del sentimiento numinoso que sería un indicio del objeto (trascendente) mismo que suscita tales sentimientos sicológicos. Pero de ese "objeto numinoso únicamente se puede dar una idea por el peculiar reflejo sentimental que provoca en el ánimo... y la expresión que más próxima se nos ofrece para compendiar todo esto es la de 'mysterium tremendum'67.

Con ese doble adjetivo, Otto encuentra la forma de expresar características fundamentales que acompañan el sentimiento numinoso. Es el temor sagrado frente al misterio indecible. Un temor que es estremecimiento (Erschütterung), producido por una fuerza absoluta desconocida (misteriosa). Y expresa esa experiencia con un texto de Goethe, con el que inicia el libro: "El estremecimiento es la parte mejor de la humanidad. Por mucho que el mundo se haga familiar a los sentidos, siempre uno sentirá lo misterioso profundamente conmovido"68 . Y los ejemplos bíblicos más relevantes para expresar ese sentimiento de lo tremendo misterioso, la toma de la experiencia de Abrahán al atreverse a pedirle a Yahvé el perdón para los habitantes de Sodoma: "He aquí que me atrevo a hablaros, yo, yo que soy polvo y ceniza” (Gn 18,27), o también la que experimenta Job al final de su discusión con Dios: "Sólo de oídas te conocía; pero ahora te han visto mis ojos. Por todo me retracto y hago penitencia en el polvo y la ceniza” (Jb 41,5-6). Al respecto, Otto comenta:

"Aquel estremecimiento primario vuelve a repetirse en la forma infinitamente ennoblecida de un temblor y enmudecimiento del espíritu, que

${ }^{66}$ Cf. R. OTTO, Lo Santo..., 17-21.

${ }^{67}$ Cf. R. Otтo, Lo Santo..., 24-25.

${ }^{68}$ R. Oтto, Lo Santo..., 7. 
llega hasta sus últimas raíces...Ha quedado convertido en místico temor y da rienda suelta, como reflejo concomitante en el sujeto, al sentimiento de criatura, de propia nulidad y anonadamiento ante lo tremendo que se experimenta. Este componente sentimental del tremor, al ser referido a un objeto numinoso que es su causa, descubre una propiedad correlativa en el numen, la cual desempeña un papel importante en nuestros textos sagrados y ha producido, a causa de su incomprensible y enigmático sentido, grandes dificultades para teólogos y exegetas"69.

De nuevo, en este comentario, se ve la distinción que hace Otto entre el sentimiento sicológico del sujeto y la referencia al objeto experimentado subjetivamente, lo cual constituye propiamente el sentimiento numinoso, sobre el que se funda la experiencia del estremecimiento y del misterio. Lo propio del misterio es precisamente su carácter indecible. Es un sentimiento cuyo referente trasciende todo lenguaje y suscita más propiamente el silencio al que antes hicimos referencia.

Pero esa misma indecibilidad confiere a la experiencia religiosa una última característica recogida por Otto: lo Fascinante. Y lo describe así:

"El contenido cualitativo de lo numinoso-que se presenta bajo la forma de misterio- está constituido de una parte por ese elemento antes descrito, que hemos llamado tremendum, que detiene y distancia con su majestad. Pero, de otra parte, es claramente algo que al mismo tiempo atrae, capta, embarga, fascina...Este enorme contraste armónico, este doble carácter de lo numinoso, se descubre a lo largo de toda la evolución religiosa. Es el hecho más singular y notable de la historia de la religión”7o.

Esa dimensión propia de lo fascinante tiene especial importancia en el contexto de nuestra sociedad del cansancio a que antes nos referimos ${ }^{71}$. Ese cansancio supone lo contrario a la experiencia fascinante, puesto que es producido por una cultura que ilusiona o "fascina" de entrada, por sus constantes novedades y aparatosa exterioridad, pero que rápidamente produce la sensación de aburrimiento o de cansancio, por su carencia de sentido de fondo. Lo cual explica la necesidad constante del cambio, al hacerse insoportable la mantención de las mismas sensaciones sin profundidad.

\footnotetext{
${ }^{69}$ R. Отто, Lo Santo..., 28-29.

$7^{70}$ R. Отто, Lo Santo..., 51.

${ }^{71}$ Nota 34 .
} 
Esa misma carencia de profundidad tiene que ver con cierta deformación del concepto oriental, y también platónico, de reencarnación, como si se tratara de una instancia que permite seguir, con esa misma superficialidad de cambios sucesivos, en otras vidas. Prefiriendo el retorno a una superficialidad en constante cambio, más que el del acceso a un cielo eterno, al final de una sola existencia en el tiempo, proyectando en ese cielo eterno la misma experiencia temporal del cansancio y aburrimiento, mantenido igual "por los siglos de los siglos".

Sin embargo, el verdadero concepto de fascinante no es estático, sino una experiencia de dinamismo eterno; es la experiencia, en Esperanza, de un fondo sin fondo, siempre nuevo, como el abismo que llama a otro abismo con el rumor de tus cascadas (Salmo 42,8). El verdadero significado de la experiencia fascinante, concomitante del sentimiento numinoso descrito por R. Otto, puede, así, constituir un factor hermenéutico muy significativo en nuestra cultura ansiosa de trascendencia, que supere las inercias religiosas consideradas a menudo irrelevantes por su falta de correlación salvífica con las carencias fundamentales de esta misma sociedad del cansancio.

\section{Concluyendo}

A la Iglesia actual le ha tocado vivir en una cultura marcada por nuevas evidencias, nuevas sensibilidades y sospechas. La fe en que es el Espíritu mismo del Jesús del Evangelio que, siendo el Verbo realmente encarnado y, por lo mismo, en un determinado espacio y tiempo, es la Palabra salvífica para todo espacio y todo tiempo, obliga a la Iglesia a inculturar esa experiencia dada en Cristo de una vez para siempre, de tal manera que todo hombre y toda mujer pueda descubrirla como salvífica para él o ella, sin la sospecha de que se le quiere imponer otra cultura correspondiente a intereses que le son ajenos.

Lo convincente del cristianismo radica, pues, sobre todo en la profunda y auténtica relación de lo que la Iglesia cree y celebra respecto al absoluto único de la Misericordia revelado plenamente en el rostro de Jesús, Verbo Encarnado, de cuyo designio salvífico participan todos los hombres de buena voluntad, en cuyo corazón actúa la Gracia de una manera invisible, 
que Dios conoce $^{72}$.. Es en relación a esa Gracia que está el lenguaje analógico de toda la dogmática, la moral, la celebración y la institucionalidad de la Iglesia. Y esa realidad a la cual apunta nuestra fe, con sus mediaciones, cuando es buscada con autenticidad, permite experimentar el sentimiento fascinante de numinosa creaturidad como indicio del tremendo misterio que nos inunda y sostiene.

\section{Bibliografía}

Acta Apostolicae Sedis, 55 (1963)

Agustín, Obras completas de San Agustín, Biblioteca de Autores Cristianos, Madrid 1994.

ALCAIN J. A., La Tradición, Universidad de Deusto, Bilbao 1998.

ARISTOTELes, Metafisica. Espasa-Calpe S.A. España 2007.

Bentué A., La experiencia bíblica: Gracia y ética, PPC, Madrid. 1997. , Dios y dioses. Historia religiosa del hombre, PUC Santiago 2004.

Bubleinikov F.D., Galileo Galilei, Montevideo 1964.

Bultmann R., Teología del Nuevo Testamento, Sígueme, Salamanca 1987.

BURnetT, M., The endurence of Life: The implications of Genetics for human life, Cambrige University Press, Londres 1978.

Byung-Chul-Han, La sociedad del cansancio, Herder, Barcelona 2017.

CASAS, B. de las, Obras completas 12. Alianza Editorial, Madrid 1990.

Congar I., La tradición y las tradiciones, I. Ensayo Histórico, II. Ensayo teológico, 1964.

CoRTINA A., Ética mínima: Introducción a la filosofía práctica, Tecnos, Madrid 1986.

Feuerbach L., La esencia del Cristianismo, Sígueme, Salamanca 1975.

Freud, S., El malestar en la cultura, en Obras completas, Biblioteca. Nueva, 1948-1968 Madrid.

HEIDEGGER, M., Ser y Tiempo, Ed. Universitaria (trad. Jorge Eduardo Rivera), Santiago 1997.

HERVIEU-LÉGER, D. La religion pour mémoire, Ed. du CERF, Paris 1993. KANT, I, Crítica de la razón pura, Sopena Argentina, Buenos Aires 1961. , La religión dentro de los límites de la mera razón, Alianza Editorial, Madrid 1969.

${ }^{72} \mathrm{GS} 22$. 
Kundera M., La insoportable levedad del ser, Tusquets, Barcelona 1984.

LAERCio D., Diógenes Laercio, vida y opiniones de los filósofos, Alianza Editorial, Madrid 2013.

LAMENNAIS: Essai sur L'indifférence en matière de religión, Flammarion, Paris 1820.

LAMPE K., The Birth of Hedonism. The Cyrenaic Philosophers and the Pleasure as a Way of Life, Princeton University Press, New Jersey 2015.

Lubac H, Histoire et esprit: l'intelligence de l'écriture d'après Origène, Du Cerf, Paris 1950.

MAINLÁNDER PH., Fỉlosofía de la Redención. Antología, Fondo de Cultura Económica, (Ed. Sandra Baquedano), Santiago de Chile 2011.

MiLAN K., La Insoportable Levedad del Ser, TusQuets, Buenos aires 2008.

NEWMan JH, "el tiempo es necesario para el desarrollo de las grandes ideas", en Ensayo sobre el desarrollo de la doctrina cristiana, Londres 1845.

Nietzsche F. La Gaya ciencia, Fontamara, México 1966. , Humano, demasiado humano, Akal, Madrid 2007.

Отто, R. Lo Santo. Lo racional y lo irracionla en la idea de Dios, Alianza Editorial Madrid 1985.

Pascal B., Pensées, Paris 1976.

PIo XII, Divino afflante spiritu: sobre el promover oportunamente los estudios de la sagrada Biblia, Sígueme, Salamanca 1965.

SABATER F., Ética como amor propio, Mondadori, Madrid 1988.

SAn Anselmo, Proslogion, BAC., Madrid 1952.

Tillich P., Theologie Sistématique, Du Cerf, Paris 1991.

Tola. D., Udana La Palabra De Buda, Buenos Aires: Trotta, 8,3.

Vattimo, G., Rovatti P. A., and Leonardo Amoroso. Il Pensiero debole, Feltrinelli, Milano 1987.

Von Hildebrand, D. Sobre la muerte, Ediciones. Encuentro, Madrid 1983.

Wittgenstein L., Tractatus lógico-philosophicus, Laia, Barcelona 1981. 